\title{
Factors Affecting Occurrence of Claims in Building Projects in Lagos State, Nigeria
}

\section{${ }^{* 1}$ AJAYI, AA; ${ }^{2}$ BABALOLA, O; ${ }^{1}$ MORAKINYO, A; ${ }^{3}$ ANJONRIN-OHU, A}

\author{
${ }^{*}$ Quantity Surveying Department, Bells University of Technology, Ota, Nigeria \\ ${ }^{2}$ Quantity Surveying Department, Obafemi Awolowo University, Ile-Ife, Nigeria \\ ${ }^{3}$ Quantity Surveying Department, The Polytechnic Ibadan, Ibadan, Nigeria \\ *Corresponding AuthorEmail: akmajayi@hotmail.com,aaajayi@bellsuniversity.edu.ng
}

\begin{abstract}
The occurrence of claims prevails in all projects, making the successful completion of projects within the predetermined budget a mirage. This is recognized to have added to costs of projects and adversely affected project performance. This paper aims at investigating critical factors influencing occurrence of claims in building projects in Lagos State, Nigeria. Forty-three (43) construction project attributes affecting project performance were identified through literature and presented to the key stakeholders in the study area using questionnaire survey. Two hundred and seventy-six (276) copies of the questionnaire were randomly administered to key stakeholders involved in the building construction process. One hundred and fifty-one (151) were retrieved representing $57.61 \%$ response rate. Principal component analysis of responses to a set of 43 characteristics identified through literature review extracted four components. The results indicated important factors such as: 'Project Participant Characteristics', 'Basic Project Characteristic', 'Procurement Characteristics', along with 'Complexity Characteristics' were factors influencing the occurrence of claims. It was concluded that the construction stakeholders should effectively manage these factors in minimising claims occurrence and thereby improving building projects delivery.
\end{abstract}

\section{DOI: https://dx.doi.org/10.4314/jasem.v25i8.29}

Copyright: Copyright (C) 2021 Ajayi et al. This is an open access article distributed under the Creative Commons Attribution License (CCL), which permits unrestricted use, distribution, and reproduction in any medium, provided the original work is properly cited.

Dates: Received: 10 May 2021; Revised: 28 June 2021; Accepted: 01 July 2021

Keyword: Building projects, Claims, Occurrence of claims, Project characteristics

Claim is considered as part and parcel of the construction process and most notably the construction industry. Seo and Kang (2019) highlighted that the upward rise in the incidence of claims is connected to the advancement in the complexity of construction projects, strict competition in the construction industry and the legal approach adopted by the two major parties to a contract. It can thus be inferred that regardless of the construction process and conditions of contract, construction contracts are susceptible to claim. Claims have become a norm in construction project delivery. The concept involves the exploring and reviewing of changes made by any of the parties to a contractual agreement during the construction process (Tochaiwat and Chovichien, 2004). Claims usually lead to a dispute which adversely affects the outcome of the construction process. Most time claims resulted in financial compensation. According to Ren et al. (2001) and Mohammed et al. (2018), disputes are now considered endemic in the construction industry. Though claims are used at times to make contractual changes in construction projects (Mohammed et al., 2018), hence they are inevitable. The tendency to find experts in disputes resolution makes a significant difference in the outcome of the disputes. Olanrewaju and Anavhe (2011) found that claims significantly occurred in almost every completed project. This led to an assertion that construction claims have become a striking feature in the construction project. For this reason, Baloi and Price, (2003, p. 261) asserted that in developing economies where there is a high level of underperformance of construction projects in terms of cost is assumed to be normal rather than the expectation. Largely, this construction projects' underperformance affects the image of the construction industry (Aljohani et al., 2017; Rahsid et al., 2013; Yahya et al., 2019) and needs an effective and efficient management process to dramatically reverse the situation. The occurrence of claims prevails in all projects, making the successful completion of projects within a predetermined budget a mirage. It is widely recognized that additional costs due to construction claim negatively influence project performance (Semple et al., 1994; Zaneldin, 2006). Causes of poor performance have been the focus of several studies for decades (Aibinu and Jagboro, 2002; Sinesilassie et al., 2017), with few empirical studies on factors affecting the occurrence of building projects claims (Diekmann and Nelson, 1985; Semple et al., 1994). Based on this fact, this study suggests certain project characteristics are impacting the successful completion of projects. Hence, there is a need to 
quantitatively investigate factors influencing the occurrence of claims in the industry. The outcome of this empirical study could help the stakeholders to have a better understanding and handling of important project characteristics to improve the building construction claims management process.

\section{MATERIALS AND METHODS}

A survey strategy was used for quantitative data collection using a well-structured questionnaire devoid of any ambiguity. The target population was limited to the key stakeholders, which comprise the Client, Consulting and Contracting organizations in Lagos State. The contracting firms that were registered with Lagos State Tender Board were involved in the study. Consultancy firms duly registered with their respective professional boards of registration (Architects Registration Council of Nigeria, ARCON and Quantity Surveyors Registration Board of Nigeria, QSRBN) were also involved, while the Client organizations were limited to Lagos State Government and Private Developers.

Preparation of questionnaire: The questionnaire designed for this research was a well-structured type and close-ended, such that the identified factors influencing the occurrence of claims from the literature have been incorporated in the questionnaire, which respondents ranked in order of preference that expresses their opinions. The questionnaires were piloted, the researchers had conducted the required modifications and suggestions on the identified factors in the questionnaire before it came into a final version. A list of forty-three (43) project characteristics emanated from a reported workshop by Favie and Maas (2008) was adopted for measuring the factors influencing the occurrence of claim in this study.

A Likert scale of five-point with numerical value 5 represents 'Highly significant', and 1 represents 'Highly insignificant' was adopted for this study, in which respondents ranked the identified factors. This approach conformed with previous studies (Ajayi et al., 2019; Sinesilassie et al., 2017). Statistical tools such as Mean score (MS), one-way analysis of variance (ANOVA) test (this was used to test the null hypothesis, that is, there is no statistically significant difference in the key stakeholders' perception of factors influencing the occurrence of claims in building projects) and factor analysis were applied using Statistical Package for the Social Sciences (SPSS) 20.0. The data was collected from November, 2018 to March, 2019.

Response rate and respondent's demographics: Out of two hundred and seventy-six (276) questionnaires that were distributed, only one hundred and fifty-nine (159) were retrieved. This indicated an approximately 58\% respondent rate. Table 1 revealed the demographic information of the respondents in this study. And this indicated client organisations $12(8 \%)$, consulting organisations had 96 respondents $(60 \%)$ and contracting organizations had 51 (32\%). Table 1 also revealed the highest percentage of staff working with the organisation is $33.3 \%$ within the range of $11-20$. However, the results indicated that the responding organisations have an average of 18 staff. In terms of highest academic qualification, above all, $69.0 \%$ of the respondents had academic qualifications not less than B.Sc./B.Tech. Also, in all, a considerable proportion $(72 \%)$ of the respondents had work experience of above 20 years and the average work experience was 12 years. Finally, it could be deduced that within the respondent's organization size, educational qualification coupled with their years of professional experience, their responses can be accurately relied upon to make reasonable decisions.

Table 1: Respondent's profile

\begin{tabular}{|c|c|c|c|}
\hline \multicolumn{4}{|l|}{ Characteristics } \\
\hline \multirow{3}{*}{ Organization } & Group & Frequency & $(\%)$ \\
\hline & Client & 12 & 8 \\
\hline & Consulting & 96 & 60 \\
\hline \multirow{6}{*}{ Company size } & Contractin & 51 & 32 \\
\hline & $\mathrm{g}$ & & \\
\hline & $0-10$ & 49 & 31 \\
\hline & $11-20$ & 52 & 33 \\
\hline & $21-30$ & 31 & 19 \\
\hline & $31-40$ & 13 & 8 \\
\hline \multirow{7}{*}{$\begin{array}{l}\text { Highest Educational } \\
\text { Qualification }\end{array}$} & Above 40 & 14 & 9 \\
\hline & Mean & & \\
\hline & 18.0 & & \\
\hline & Ph. D. & 2 & 1 \\
\hline & M. Sc. & 58 & 36 \\
\hline & B. Sc and & 50 & 32 \\
\hline & B. Tech. & & \\
\hline \multirow{8}{*}{$\begin{array}{l}\text { Work Experience of } \\
\text { Respondent (years) }\end{array}$} & H. N. D & 49 & 31 \\
\hline & $0-5$ & 22 & 14 \\
\hline & $6-10$ & 47 & 30 \\
\hline & $11-15$ & 45 & 28 \\
\hline & $16-20$ & 28 & 18 \\
\hline & Above 20 & 17 & 11 \\
\hline & Mean = & & \\
\hline & 12.0 & & \\
\hline
\end{tabular}

\section{RESULTS AND DISCUSSION}

Means score ranking of identified factors: Table 2 presents the mean score (MS) for the factors influencing the occurrence of construction claims according to the opinions of each stakeholder. All the forty-three (43) project characteristics identified were highly ranked with MS ranged between $4.16 \leq 2.77$ which showed ranking above average. A total of thirty (30) out of the forty-three (43) identified project characteristics had MS greater than 3.00, representing $70 \%$. Though, the remaining 13 (30\%) project characteristics fell in the group of MS less than 3.00. 
Table 2: Factors influencing the occurrence of construction claims

\begin{tabular}{|c|c|c|c|c|c|c|c|c|c|}
\hline \multirow[t]{2}{*}{ Factors } & \multicolumn{2}{|c|}{ Client } & \multicolumn{2}{|c|}{ Consulting } & \multicolumn{2}{|c|}{ Contracting } & \multicolumn{2}{|c|}{ Overall } & \multirow[b]{2}{*}{ Rk } \\
\hline & MS & $\mathbf{R k}$ & MS & $\mathbf{R k}$ & MS & $\mathbf{R k}$ & MS & $P$-value & \\
\hline $\begin{array}{l}\text { Complexity of project (e.g. special ground } \\
\text { conditions or technology requirements). }\end{array}$ & 3.58 & 1 & 4.04 & 1 & 4.63 & 1 & 4.16 & $0.000 *$ & 1 \\
\hline $\begin{array}{l}\text { Effects of relevant political, legal and economic } \\
\text { systems, including market conditions. }\end{array}$ & 2.83 & 27 & 3.53 & 3 & 4.61 & 2 & 3.82 & $0.027 *$ & 2 \\
\hline Technical approval authorities & 3.17 & 14 & 3.73 & 2 & 3.41 & 12 & 3.62 & 0.177 & 3 \\
\hline $\begin{array}{l}\text { Payment mode to the contractor (payment } \\
\text { modalities such as fixed-price or cost-plus fee) }\end{array}$ & 3.33 & 9 & 3.43 & 7 & 3.55 & 11 & 3.46 & 0.776 & 4 \\
\hline $\begin{array}{l}\text { Nature and status of local construction industry, } \\
\text { including available capacities of potential project } \\
\text { participants, scarcity of work in particular fields, } \\
\text { competitiveness. }\end{array}$ & 2.92 & 25 & 3.47 & 5 & 3.57 & 9 & 3.46 & 0.155 & 4 \\
\hline $\begin{array}{l}\text { Type of client (e.g. public/private/mixed; } \\
\text { experienced/one-off/project staff calibre and their } \\
\text { strengths). }\end{array}$ & 3.00 & 20 & 3.34 & 10 & 3.76 & 6 & 3.45 & $0.024 *$ & 6 \\
\hline $\begin{array}{l}\text { The extent to which bid documents allow additions } \\
\text { to the scope }\end{array}$ & 3.50 & 2 & 3.51 & 4 & 3.25 & 20 & 3.43 & 0.374 & 7 \\
\hline $\begin{array}{l}\text { Size of project (e.g. value; number of stories; floor } \\
\text { area; } \mathrm{km} \text { of road). }\end{array}$ & 2.83 & 27 & 3.28 & 14 & 3.84 & 4 & 3.43 & 0.001* & 7 \\
\hline Level of technological advancement & 3.00 & 20 & 3.22 & 15 & 3.82 & 5 & 3.40 & $0.001 *$ & 9 \\
\hline Level of specialization required of contractors & 3.33 & 9 & 3.39 & 8 & 3.35 & 14 & 3.37 & 0.977 & 10 \\
\hline Ownership of building & 3.50 & 2 & 3.47 & 5 & 3.05 & 29 & 3.34 & $0.049 *$ & 11 \\
\hline $\begin{array}{l}\text { Form of contract (functional grouping of contract: } \\
\text { separated or integrated) and the division of } \\
\text { responsibilities and liabilities }\end{array}$ & 3.42 & 7 & 3.14 & 20 & 3.67 & 7 & 3.33 & $0.025 *$ & 12 \\
\hline $\begin{array}{l}\text { Specific location, special weather and } \\
\text { environmental concerns. }\end{array}$ & 2.50 & 39 & 3.02 & 29 & 4.00 & 3 & 3.30 & $0.000 *$ & 13 \\
\hline Project Fund & 3.50 & 2 & 2.99 & 31 & 3.57 & 9 & 3.21 & 0.006* & 14 \\
\hline $\begin{array}{l}\text { Local familiarity and confidence in/disillusionment } \\
\text { with, particular types of procurement with reasons. }\end{array}$ & 3.08 & 18 & 3.31 & 12 & 3.04 & 30 & 3.21 & 0.314 & 14 \\
\hline Importance for the project to be delivered & 3.00 & 20 & 3.16 & 18 & 3.31 & 15 & 3.20 & 0.641 & 16 \\
\hline Contractual arrangement & 3.33 & 9 & 3.35 & 9 & 2.84 & 38 & 3.18 & 0.400 & 17 \\
\hline $\begin{array}{l}\text { Importance for the project to be completed within } \\
\text { budget }\end{array}$ & 3.25 & 13 & 3.30 & 13 & 2.92 & 36 & 3.17 & 0.174 & 18 \\
\hline $\begin{array}{l}\text { Type of project (e.g. housing estate, road, dam, } \\
\text { office building refurbishment). }\end{array}$ & 2.42 & 42 & 3.04 & 27 & 3.59 & 8 & 3.17 & $0.000 *$ & 18 \\
\hline $\begin{array}{l}\text { Performance of available contractors and consultants } \\
\text { on previous (similar) projects in the area in terms of } \\
\text { meeting cost, quality and time targets; safety records } \\
\text { and client satisfaction levels: as compared with the } \\
\text { procurement modalities used. }\end{array}$ & 3.50 & 2 & 3.07 & 25 & 3.27 & 17 & 3.17 & 0.376 & 18 \\
\hline $\begin{array}{l}\text { Project scope definition completion when bids are } \\
\text { invited }\end{array}$ & 3.17 & 14 & 3.18 & 16 & 3.10 & 26 & 3.15 & 0.939 & 21 \\
\hline $\begin{array}{l}\text { Availability of information at project inception and } \\
\text { points at which any remaining information will be } \\
\text { required/be available. }\end{array}$ & 2.83 & 27 & 3.11 & 22 & 3.31 & 15 & 3.15 & 0.336 & 21 \\
\hline Quality of a project & 3.08 & 17 & 3.18 & 16 & 3.06 & 27 & 3.13 & 0.822 & 23 \\
\hline Importance for the project to be completed on time & 2.67 & 36 & 3.14 & 20 & 3.18 & 21 & 3.12 & 0.191 & 24 \\
\hline Bidder's knowledge of the budget & 3.00 & 20 & 3.32 & 11 & 2.76 & 40 & 3.12 & 0.018* & 24 \\
\hline $\begin{array}{l}\text { Selection process/methodology (bidding procedure, } \\
\text { number of bidders, selection criteria, bidding } \\
\text { environment) }\end{array}$ & 3.33 & 9 & 3.05 & 26 & 3.14 & 23 & 3.10 & 0.661 & 26 \\
\hline Value of a project & 3.50 & 2 & 3.01 & 30 & 3.14 & 23 & 3.09 & 0.283 & 27 \\
\hline project life span/lifecycle & 2.75 & 33 & 2.98 & 33 & 3.37 & 13 & 3.09 & 0.075 & 27 \\
\hline $\begin{array}{l}\text { The flexibility of scope of works when a contractor } \\
\text { is hired }\end{array}$ & 3.17 & 14 & 3.09 & 24 & 3.06 & 27 & 3.09 & 0.954 & 27 \\
\hline The density of a project & 3.42 & 7 & 2.94 & 35 & 3.27 & 17 & 3.08 & 0.123 & 30 \\
\hline Present of repetitive elements & 2.75 & 33 & 3.10 & 23 & 2.84 & 38 & 2.99 & 0.404 & 31 \\
\hline Bid evaluation and selection criteria & 2.83 & 27 & 2.83 & 38 & 3.27 & 17 & 2.97 & 0.086 & 32 \\
\hline $\begin{array}{l}\text { Availability of materials and equipment that are } \\
\text { required for the works. }\end{array}$ & 2.83 & 27 & 3.15 & 19 & 2.63 & 43 & 2.96 & $0.031 *$ & 33 \\
\hline Bidding environment & 2.50 & 39 & 2.92 & 36 & 3.14 & 23 & 2.96 & 0.252 & 33 \\
\hline Design completion when budget is fixed & 2.67 & 36 & 2.95 & 34 & 3.04 & 30 & 2.96 & 0.630 & 33 \\
\hline Prequalification or short-listing & 2.25 & 43 & 2.99 & 31 & 3.04 & 30 & 2.95 & 0.132 & 36 \\
\hline Presence of special issues & 2.92 & 25 & 2.90 & 37 & 3.04 & 30 & 2.95 & 0.815 & 36 \\
\hline Any other special conditions & 2.50 & 39 & 3.03 & 28 & 2.76 & 40 & 2.90 & 0.228 & 38 \\
\hline Time given to contractor to bid & 3.00 & 20 & 2.81 & 40 & 3.00 & 35 & 2.89 & 0.586 & 39 \\
\hline $\begin{array}{l}\text { Th extent to which the contractor period is allowed } \\
\text { to vary during bid evaluation stage }\end{array}$ & 3.08 & 18 & 2.74 & 41 & 2.92 & 36 & 2.82 & 0.470 & 40 \\
\hline Type of specification & 2.83 & 27 & 2.83 & 38 & 2.76 & 40 & 2.81 & 0.944 & 41 \\
\hline Time given to owners/consultants to evaluate bids & 2.75 & 33 & 2.70 & 42 & 3.02 & 34 & 2.81 & 0.197 & 41 \\
\hline Number of bidders & 2.67 & 36 & 2.57 & 43 & 3.16 & 22 & 2.77 & 0.018* & 43 \\
\hline
\end{tabular}

$*$ The one-way ANOVA result was significant at the 0.05 level Rk=Rank; MS = Mean Item Score 
The most influential factors related to project characteristic was found to be "complexity of project" $(\mathrm{MS}=4.16)$ was ranked 1st, "effects of political, legal and economic systems" (MS=3.62) was ranked 2nd, "technical approval" (MS=3.62) was ranked 3rd, and "payment mode to the contractor" $(\mathrm{MS}=3.46)$ was ranked 4 th.

The overall response column in Table 2 shows "complexity of project" (4.16), "political, legal and economic systems effects" (3.82), "technical approval authorities" (3.62), and "mode of paying contractor" (3.46), as indicated by their decreasing MS's with ranked $1 \mathrm{st}, 2 \mathrm{nd}$, 3rd, and 4th respectively indicating 'complexity of project' as the most significant project characteristic. Conversely, the least three influential project characteristics included "type of specification" (2.81), "time given to owner/consultants to evaluate bids" (2.81), and "number of bidders" (2.77). This shows that most of the least influential project characteristics are dominantly the consultants' views. The MS ranking shows "project's complexity" as the most highly ranked factor. This can be gauged from the fact that almost all the surveyed organizations have this ranked high in their responses, believed that definitely, the more complex a project is, and the more numbers of claims likely to be raised. This is against the study of Diekmann and Nelson (1985) who observed change orders and modifications originated with clients and frequency of design error influence occurrence of construction claims. In determining the opinions agreement of the key stakeholders on the factors affecting the occurrence of claims, a null hypothesis $\left(\mathrm{H}_{0}\right)$ was drawn: no statistically significant difference in the key stakeholders' perception. ANOVA test was conducted and the result (at 0.05 significance level) shows that only 13 out of 43 project characteristics identified by this study were very significant (see Table 3). This indicated a different opinion on the thirteen (13) factors influencing the occurrence of claims (with $p$-value $<0.05$ ), hence, the dismissal of the null hypothesis. It means all the stakeholders were of divergent opinions. Factor analysis: In carrying out the factor analysis, the adequacy and suitability of the sample size were assessed using the Kaiser-MeyerOlkin (KMO) Sampling Adequacy Test and Bartlett's Test of Sphericity. The results indicated Bartlett's Test of Sphericity was 2023.723 and the associated significance level was 0.000 . Also, the sample accuracy measured with Kaiser-Meyer-Olkin (KMO) returned a value of 0.871 , which is very large and within the stipulated threshold of $\geq 0.7$ (Hair et al., 2009). Therefore, factor analysis is feasible with the sampled data. In addition, the principal component communalities (PCC) were assessed and this indicated extraction range from 0.822 to 0.595 , as the Initials are always 1.000. It should be noted that out of the 43 factors, only 18 factors were selected based on a highly significant correlation. The remaining 13 factors were found to have no significant correlation with one another and hence they were excluded from further analysis. This conforms to the claim of Larose (2006), that any commonality below 0.5 is assumed weak. The application of factor analysis was to model the influence of project characteristics on the occurrence of claims to compare the results. This is to compare and check whether the above deductions could be improved upon. The factor analysis categorized the 18 selected factors into four components as seen in Table 3.

Component I: Project Participant Characteristics: The first component tagged 'project participant characteristics' has ten (10) factors with a strong association that accounted for $48.69 \%$ of the total variance. The associations in this component were logical as these factors are all fundamental to occurrences of claims and ultimately affect project cost. 'Project scope definition' with a factor loading of $84 \%$ was strongly associated with this component (see Table 3). This dimension measures the efficiency of project execution and ensures that the project is done right. The findings here strengthened the viewpoint presented in the (PMI, 2000) that scope changes have a significant impact on the project cost. Scope changes are considered inherent in the nature of projects because of their complexity and the inevitable appearance of unforeseen problems (Ertel, 2000). Therefore, the extent to which bid documents allow changes to scope, influence the occurrence of claims.

Component II: Basic Project Characteristics: Component two, named "basic project characteristics" explains that $9.55 \%$ of the total variance of the linear component comprises three key factors. The factors, "complexity of project", "size of project", and "type of project" have loading factors of $0.825,0.803$ and 0.743 respectively. (see Table 3 ). The finding, here, showed that there was a statistically significant correlation among the three factors within the basic project characteristics dimension. The term "complexity of project" is how complex the project is by either involving special ground conditions or the level of technology that will be required for the project. According to Baccarini (1996), project complexity was to be founded on two key concepts, namely: differentiation and interdependency where differentiation refers to the number of varied tasks and interdependency to the degree of interrelatedness amongst those tasks. Also, the need for specialized sub-contractors, unexpected ground conditions and overlap between the design and construction process 
cumulate to form project complexity. Nevertheless, the complexity of a project construes with the construction project size. The larger the size of the project, the probability of the project being complex is high.

\begin{tabular}{|c|c|c|}
\hline Factor Name & $\begin{array}{l}\text { Factor } \\
\text { Loading }\end{array}$ & $\begin{array}{l}\% \text { Variance } \\
\text { explained }\end{array}$ \\
\hline \multicolumn{3}{|l|}{$\begin{array}{l}\text { Component I: Project Participant } \\
\text { Characteristics }\end{array}$} \\
\hline $\begin{array}{l}\text { Project scope definition completion when bids } \\
\text { are invited }\end{array}$ & 0.840 & 48.69 \\
\hline $\begin{array}{l}\text { Ownership of materials and equipment that are } \\
\text { required }\end{array}$ & 0.741 & \\
\hline Bidder's knowledge of the budget & 0.728 & \\
\hline $\begin{array}{l}\text { The extent to which bid documents allow } \\
\text { additions to the scope }\end{array}$ & 0.703 & \\
\hline Present of repetitive elements & 0.700 & \\
\hline Contractual arrangement & 0.695 & \\
\hline $\begin{array}{l}\text { Flexibility of scope of works when contractor is } \\
\text { hired }\end{array}$ & 0.692 & \\
\hline Quality of a Project & 0.656 & \\
\hline $\begin{array}{l}\text { Importance of project to be completed within } \\
\text { budget }\end{array}$ & 0.628 & \\
\hline Value of a project & 0.587 & \\
\hline \multicolumn{3}{|l|}{ Component II: Basic Project Characteristics } \\
\hline Complexity of project & 0.825 & 9.55 \\
\hline Size of project & 0.803 & \\
\hline Type of project & 0.743 & \\
\hline \multicolumn{3}{|l|}{ Component III: Procurement Characteristics } \\
\hline Selection process/methodology & 0.809 & 6.97 \\
\hline Form of Contract & 0.671 & \\
\hline Importance of project to be delivered & 0.623 & \\
\hline \multicolumn{3}{|l|}{ Component IV: Complexity Characteristics } \\
\hline Level of technological advancement & 0.821 & 6.18 \\
\hline $\begin{array}{l}\text { Importance for the project to be completed on } \\
\text { time }\end{array}$ & 0.778 & \\
\hline
\end{tabular}

Extraction Method: Principal Component Analysis: Rotation Method: Varimax with Kaiser Normalization. Rotation converged in 6 iterations: Component III: Procurement Characteristics: This component also named Procurement Characteristics explained $6.97 \%$ of the total variance of the linear component comprises the three factors. From the three strongly loading variables in this component (see Table 3), "selection process/ methodology" (with a loading factor of $80.9 \%$ ) is the highest. This is in agreement with the suggestion of Alhazmi and McCaffer (2000), that the processing of contractor's selection is very important and has a big influence on the project and its success.

Component IV: Complexity Characteristics: This complexity characteristics component is a cluster that accounted for $6.18 \%$ of the total variance, in which the "level of technological advancement" has a loading factor of 0.821. Support for technological advancement helps to improve construction competitiveness. Technological advancements in construction process have resulted in building projects complexity growth (Gidado, 2004). This change has in recent times influenced production rates, techniques and procedures. This result is expected, as the adaptation of advanced technology will lead to completion of the project within a predetermined time.

Conclusion: Based on the analysis results, it can be concluded that the key stakeholders (clients, consultants and contractors) need to fully appreciate the importance of critical factors influencing the occurrence of construction claims. Thus, the stakeholders' focus should be on effective management of the project scope definition completion when bids are invited, project complexity, contractors' selection process, and technological advancement level required for the project.

\section{REFERENCES}

Aibinu, AA; Jagboro, GO (2002). The effects of construction delays on project delivery in Nigerian construction industry. Internl. J. Proj. Manage. 20(2): 593-599

Ajayi, AA; Babalola, O; Mafimidiwo, B (2019). Construction project claim management process in Nigeria: Status, barriers and impact. In: Babalola et al. (eds.) Drivers and Dynamics of Change in the 
Built Environment. EDMIC2019, OAU, Ile-Ife, p.179.

Alhazmi, T; McCaffer, R (2000). Project procurement system selection model. J. Constr. Eng. Manage. 126(3): 176-184.

Aljohani, A; Ahiaga-Dagbui, D; Moore, D (2017). Construction Projects Cost Overrun: What Does the Literature Tell Us? Internl. J. Innov. Manage. Technol. 8(2): 137-43.

Baccarini, D (1996). The concept of project complexity - a review. Intern. J. Proj. Manage. 14(4): 201-204.

Baloi, D; Price, ADF (2003). Modelling global risk factors affecting construction cost performance. Internl. J. Proj. Manage. 21(4): 261-269.

Diekmann, JE; Nelson, MC (1985). Construction claims: frequency and severity. J. Constr. Engin. Manage.

111(1): https://doi.org/10.1061/(ASCE)07339364(1985)111:1(74)

Ertel, D; Rudner, S (2000). Scope change negotiations: A write-off inevitable? Consult. Manage. 11(2): 38.

Favie, R; Maas, GJ (2008). Ranking Construction Project Characteristics. In: Carter K; Ogunlana S; Kaka A (eds) Transformation Through Construction International Council for Research and Innovation in Building and Construction (CIB), Dubai, p. 1-8.

Gidado, K. (2004). Enhancing the prime contractor's pre-construction planning. J. Constr. Research 5(1): 87-106.

Hair, JF; Black, B; Babin, B (2009). Multivariate data analysis: A global perspective 7 th ed.. Prentice Hall, N.J.

Larose, DT (2006). Data mining methods and models. John Wiley and Sons, Hoboken, N.J.

Mohammed, SHNM; Gautham, B; Behzad, E; Ghada, G. (2018). Claims and Project Performance between Traditional and Alternative Project Delivery Methods. J. of Leg. Aff. Dispute. Resolut. Eng. Constr. 10(3); 04518017
Olanrewaju, AA; Anavhe, PJ (2011). Construction claim factors in the Nigerian built environment. Proceedings, 6th International Conference on Construction in the 21st Century: Construction Challenges in The New Decade, Kuala Lumpur Malaysia.

Project Management Institute (PMI) (2000). A guide to the project management body of knowledge (PMBOK). Project Management Institute, Upper Darby, P.A.

Rahsid, Y; Haq, S; Aslam, S (2013). Causes of delay in construction projects of Punjab-Pakistan: An empirical study. J. Basic Appl. Sci. Res. 3(10): 8796.

Ren, Z; Anumba, GJ; Ugwu, OO (2001). Construction claims management: towards an agent-based approach. Eng. Constr. Architect. Manage. 8(3): 185-197.

Semple, C; Hartman, T; Jergeas, G (1994). Construction claims and disputes: Causes and cost/time overruns. J. Constr. Eng. Manage. 120(4): 785-795

Seo, W; Kang, Y (2019). Performance indicators for the claim management process of construction projects. Amer. Soc. Civil Eng. ASCE. 611617. http://doi.org/10.1061/9780784482421.077

Sinesilassie, EG; Tabish, SZS; Jha, KN (2017). Critical factors affecting cost performance: a case of Ethiopian public construction projects. Internl. J. Constr. Manage, 18(2), 108-119.

Tochaiwat, K; Chovichien, V (2004). Contractors' construction claims and claim management process. Research Dev. J. Eng. Institute of Thailand 15(4): 66-73.

Yahya, MY; Abba, WA; Mohamed, S; Yassin, AM (2019). Contributing factors of poor construction project performance in Nigeria. Internl. J. Prop. Sci. 9(1): https://doi.org/10.22452/ijps.vol9no1.1

Zaneldin, E (2005). Construction claims in the United Arab Emirates: Types, causes, and frequency. In: Khosrowshahi F (ed) ARCOM Conference Vol. 2, SOAS, University of London, p. 813-822. 